\title{
Risk Factor Analysis of HIV/AIDS Transmission to Loading Workers in Port of Padang City
}

\author{
Sri Mindayani ${ }^{1^{*}}$, Hilda Hidayat ${ }^{1}$ \\ ${ }^{1}$ Public Health Faculty Universitas Baiturrahmah, Padang, Indonesia \\ *Corresponding author. Email: srimindayani@fkm.unbrah.ac.id
}

\begin{abstract}
The results of the initial survey at the Public Health Center in the port area of Padang City, showed a trend of increasing cases of HIV/AIDS. In 2014 there were 15 cases, in 2015 there were 21 cases and in 2016 there were 24 cases. The purpose of this study was to analyze risk factor of HIV/AIDS transmission to loading workers in port of Padang City. This type of research was analytic with cross sectional design. This research was conducted from January to May 2019 in the port of Padang City. The study population numbered 834 people and the total sample were 90 people. Sampling was done by cluster sampling technique. Primary data collection is done by interview using a questionnaire. Data analysis includes univariate and bivariate analysis. The results showed a relationship between social pressure with risk behaviors for transmitting HIV/AIDS (P value $=0.011)$, no relationship between perception of vulnerability with risk behavior transmission of HIV/AIDS $(\mathrm{P}$ Value $=0.103$ ) and no relationship between knowledge with risk behaviors for transmitting HIV/AIDS (P Value $=1.00)$.
\end{abstract}

Keywords: behavior, HIV /AIDS, loading workers

\section{INTRODUCTION}

Indonesia represents the country with the highest number of HIV cases in Southeast Asia with an estimated 48,000 cases. In ASIA, Indonesia places the largest number in HIV/AIDS cases [1]. The number of HIV cases in Indonesia is currently increasing from year to year. In 2014 there were 32,711 cases, in 2015 there were 30,395 cases and in 2016 there were 41,250 cases. The highest cumulative AIDS percentage is in the age group of 20-29 years (31.4\%) and based on the sex of men as much as $56 \%$ [2].

HIV AIDS in Indonesia is concentrated in certain population groups [3]. Key populations in this relationship: female sex workers (WPS), injecting drug users (IDUs), male sex with men (MSM), and transsexuals, convicts, pregnant women and Potential Risti Men (sailors, truck drivers, and loading / unloading workers) [4].

A loading worker is a man who has the potential to become a WPS customer (5). Based on the 2015 STBP, the number of HIV/AIDS cases in the number of loading workers in 2007 was $0.8 \%$, in 2011 it increased to $0.7 \%$ and in 2015 it increased to $0.82 \%$ (6). Only $0.75 \%$ of loading workers always use condoms when having the last section (6). The results of an analysis of risk behaviors towards HIV in Indonesia in 2009 showed that $50 \%$ of male loading workers had a preference for sex [5].

Data from the Padang City Health Office in 2017, shows the number of HIV cases as many as 300 people, the highest number in men is 297 people and in women 71 people [7].
Kota Padang has a seaport managed by PT. Pelindo II Teluk Bayur, where there are two areas namely in Teluk Bayur and Muara Padang. Loading workers are managed solely by the Teluk Bayur Unloading Labor Cooperative (KOPERBAM). The number of loading workers is 782 while 722 people are located in Teluk Bayur and 60 people in Muara Padang. The results of the initial survey at the public health center in the port area of Padang City showed an increasing trend of HIV/AIDS cases. In 2014 there were 15 cases, in 2015 there were 21 cases and in 2016 there were 24 cases [8].

The results of an interview with KOPERBAM Teluk Bayur, it is known that some Loading Worker people have a risk of contracting HIV/AIDS, where there are sex purchase activities by loading workers. This is because the location of the port is close to the location of prostitution in the city of Padang. Even though the location of prostitution does not include localization, but at this location, it is always a prostitution activity. The close distance between the port and the location of prostitution, causing the loading worker has easy access to carry out activities at risk of contracting HIV/AIDS. Based on the above problem, the researcher is interested in researching the analysis of HIV/AIDS risk behavior in loading workers in the Port of Padang City in 2018.

The general objective of this research is to study the risk analysis for HIV/AIDS transmission at loading workers in the Port of Padang City. The specific objective in this research is to study the relationship between social pressure, perception of vulnerability and knowledge with risk behavior transmission of HIV/AIDS. 


\section{METHOD}

This type of research is analytic with a cross-sectional design. This research was conducted from January - May 2019 at the Port of the City of Padang. The study population numbered 834 people and a sample of 90 people. Sampling was done by a cluster sampling technique. Primary data collection is done by interview using a questionnaire. Data analysis included univariate analysis, bivariate analysis to test whether there was a relationship between the independent variable and the dependent variable using the chi-square test at a 95\% confidence level ( $p<0.05)$. The dependent variable in this study is the prevention of HIV / AIDS transmission and the independent variable, namely social pressure, knowledge and perception of vulnerability.

\section{RESULTS AND DISCUSSION}

\section{Results}

\section{Univariate Analysis}

a. Social Pressure

The results of the frequency distribution of social pressure on loading workers can be seen in table 1 .

Table 1

Frequency Distribution of Social Pressure in Loading Workers at Port of Padang City in 2019

\begin{tabular}{cccc}
\hline No & Social Pressure & f & \% \\
\hline 1 & Good & 56 & 62,2 \\
2 & Not Good & 34 & 37,8 \\
\hline & Total & $\mathbf{9 0}$ & $\mathbf{1 0 0 \%}$ \\
\hline
\end{tabular}

Based on table 1. it can be seen that as many as $37.8 \%$ of loading workers get bad social pressure at the Port of Padang City in 2019.

The following is a description of the answers based on the social pressure of loading workers, as presented in table 2 . as follows:

Table 2

Frequency Distribution of Social Pressure Questionnaire Answers on Loading Workers at Padang City Port in 2019

\begin{tabular}{llll}
\hline No & Statement & Yes & No \\
\hline
\end{tabular}

\begin{tabular}{clcccc}
\hline & f & \% & f & \% \\
\hline 1. & $\begin{array}{l}\text { The use of narcotic } \\
\text { drugs by friends }\end{array}$ & 22 & 24,4 & 68 & 75,6 \\
\hline 2. & $\begin{array}{l}\text { Invite friends to use } \\
\text { narcotics }\end{array}$ & 9 & 10 & 81 & 90 \\
\hline 3. & $\begin{array}{l}\text { Friends have sexual } \\
\text { relations freely } \\
\text { (changing partners)? }\end{array}$ & 18 & 20 & 72 & 80 \\
\hline 4. & $\begin{array}{l}\text { Friends invite } \\
\text { loading workers to } \\
\text { have sex freely } \\
\text { (changing partners)? }\end{array}$ & 17,9 & 73 & 81,1 \\
\hline 5. & $\begin{array}{l}\text { The loading worker } \\
\text { friend has same-sex } \\
\text { sexual relations }\end{array}$ & 3 & 3,3 & 87 & 96,7 \\
\hline 6 & $\begin{array}{l}\text { Friends have invited } \\
\text { same-sex sexual } \\
\text { relations with } \\
\text { loading workers }\end{array}$ & 1,1 & 89 & 98,9 \\
\hline
\end{tabular}

Based on table 2 it can be seen that as many as (24.4\%) in the last year got friends who used narcotics and as many as $(10 \%)$ loading workers had been invited by friends using narcotics.

\section{b. Perception of Vulnerability}

The results of research on the perception of vulnerability in workers can be seen in table 3 :

Table 3.

Frequency Distribution of Perception of Vulnerability in Loading Workers at the Port of Padang City in 2019:

\begin{tabular}{cccc}
\hline No & $\begin{array}{l}\text { Perception of } \\
\text { Vulnerability }\end{array}$ & f & \% \\
\hline 1 & Good & 35 & 38,9 \\
2 & Not Good & 55 & 61,1 \\
\hline & Total & $\mathbf{9 0}$ & $\mathbf{1 0 0 \%}$ \\
\hline
\end{tabular}

Based on table 3 it can be seen that more than half of $61.1 \%$ of loading workers have a bad perception of severity about the impact of contracting HIV / AIDS in Padang City Port in 2019.

The following is a description of respondents' answers based on the perception of the severity of the loading workers regarding the impact if loading workers contract HIV / AIDS, as presented in table 4 as follows: 
Table 4.

Frequency Distribution of Perception of Vulnerability of Loading Workers in Padang City Port in 2019

\begin{tabular}{|c|c|c|c|c|c|c|c|c|c|c|c|}
\hline \multirow[t]{2}{*}{ No } & \multirow{2}{*}{ Statement } & \multicolumn{2}{|c|}{$\begin{array}{l}\text { Strongly } \\
\text { agree }\end{array}$} & \multicolumn{2}{|c|}{ Agree } & \multicolumn{2}{|c|}{ Neutral } & \multicolumn{2}{|c|}{ Disagree } & \multicolumn{2}{|c|}{$\begin{array}{l}\text { Strongly } \\
\text { Disagree }\end{array}$} \\
\hline & & $\mathbf{f}$ & $\%$ & f & $\%$ & $\mathbf{f}$ & $\%$ & f & $\%$ & $\mathbf{f}$ & $\%$ \\
\hline 1 & Loss of a job & 8 & 8,9 & 54 & 60 & 17 & 18,9 & 6 & 6,7 & 5 & 5,6 \\
\hline 2 & $\begin{array}{l}\text { The treatment costs are } \\
\text { expensive and cannot be } \\
\text { cured }\end{array}$ & 5 & 5,6 & 54 & 60 & 10 & 11,1 & 20 & 22,2 & 1 & 1,1 \\
\hline 3 & $\begin{array}{l}\text { Excommunicated family } \\
\text { and friends }\end{array}$ & 7 & 7,8 & 50 & 55,6 & 2 & 2,2 & 29 & 32,2 & 2 & 2,2 \\
\hline 4 & Shame & 11 & 12,2 & 66 & 73,3 & 5 & 5,6 & 8 & 8,9 & & \\
\hline 5 & Lost future & 11 & 12,2 & 60 & 66,7 & 5 & 5,6 & 11 & 12,2 & 3 & 3,3 \\
\hline
\end{tabular}

Based on table 4. it can be seen that more than half of the $60 \%$ loading workers agree the impact of contracting HIV / AIDS.

\section{c. Knowledge}

The results of research on HIV / AIDS transmission and prevention knowledge conducted on 90 loading workers obtained data as below:

Table 5

Frequency Distribution of Loading Workers' Knowledge at Padang City Port in 2019

\begin{tabular}{cccc}
\hline No & Knowledge & f & \% \\
\hline 1 & Good & 52 & 57,8 \\
2 & Not good & 38 & 42,2 \\
\hline & Total & $\mathbf{1 0 0}$ & $\mathbf{1 0 0 \%}$ \\
\hline
\end{tabular}

The results showed that $38 \%$ of loading workers had poor knowledge and $52 \%$ of loading had good knowledge of HIV / AIDS transmission and prevention in Padang City Port in 2019.

The following is a description of respondents 'answers based on the knowledge of workers' loading on HIV / AIDS transmission, as presented in table 6 as follows:

Table 6

Frequency Distribution of the Loading Questionnaire Knowledge Knowledge Questionnaire on Transmission of HIV / AIDS in Padang City Port in 2019

\begin{tabular}{llcccc}
\hline \multirow{2}{*}{ No } & \multicolumn{2}{c}{ Statement } & \multicolumn{2}{c}{ Right } & \multicolumn{2}{c}{ Wrong } \\
\cline { 2 - 6 } & f & $\%$ & f & $\%$ \\
\hline 1 & Definition of HIV & 64 & 71,1 & 26 & 28,9 \\
2 & Mode of transmission of HIV & 73 & 81,1 & 17 & 18,9 \\
3 & Prevent HIV by avoiding the use of contaminated & 67 & 74,4 & 23 & 25,6 \\
& needles & & & & \\
4 & The use of condoms can prevent HIV transmission & 49 & 54,4 & 41 & 45,6 \\
5 & The HIV vinus can be transmitted through perspiration & 21 & 23,3 & 69 & 76,7 \\
6 & Exchanging clothing with people with HIV can calse a & 23 & 25,6 & 67 & 74,4 \\
& person to contract the HIV virus & & & & \\
7 & HIV can be transmitted through blood transfusions & 80 & 88,9 & 10 & 11,1 \\
8 & Sharing using a razor can transmit HIV & 73 & 81,1 & 17 & 18,9 \\
\hline
\end{tabular}

The results of the questionnaire analysis found that loading workers did not know about HIV not transmitted through sweating (76.7\%) and HIV was not transmitted through exchanging clothes $(74.4 \%)$.

\section{d. HIV/AIDS Risk Behavior}

A description of HIV / AIDS risk behavior in loading workers in the Port of Padang City can be seen in table 7:

Table 7.

Frequency Distribution of HIV / AIDS Risk Behavior in Loading Workers at Padang City Port in 2019

\begin{tabular}{clccc}
\hline No & \multicolumn{2}{c}{ Risk Behavior } & f & \% \\
\hline 1 & No Risk & 56 & 62,2 \\
2 & Risky & Total & 34 & 37,8 \\
\hline \multicolumn{2}{r}{} & 90 & $\mathbf{1 0 0}$ \\
\hline
\end{tabular}

Based on table 7. it can be seen that as many as $62.2 \%$ of loading workers in the Port of Padang City do not have a risk-free behavior in the transmission of HIV / AIDS.

The following is a description of loading workers answers based on HIV / AIDS risk behavior as presented in table 8 as follows:

Table 8

Frequency Distribution of Questionnaire for HIV / AIDS Risk Behavior inLoading Workers at Padang City Port in 2019

\begin{tabular}{|c|c|c|c|c|c|}
\hline \multirow{2}{*}{$\mathrm{N}_{0}$} & \multirow{2}{*}{ Pertanyaan } & \multicolumn{2}{|c|}{ Ya } & \multicolumn{2}{|c|}{ Tidak } \\
\hline & & $\mathrm{f}$ & $\%$ & $\mathrm{f}$ & $\%$ \\
\hline 1. & Narcotics use & 1 & 1,1 & 89 & 98,9 \\
\hline 2. & Inject narcotics together & 1 & 1,1 & 89 & 98,9 \\
\hline 3. & Having sexual relations with different people & 19 & 21,1 & 71 & 78,9 \\
\hline 4. & Use of condoms during sexulal intercourse & 24 & 26,7 & 66 & 73,3 \\
\hline 5. & Always use a condom when having sex & 15 & 16,7 & 75 & 83,3 \\
\hline 6 & Have been forced into sexual relations with other people & 10 & 11,1 & 80 & 88,9 \\
\hline 7 & Having anal intercourse & 6 & 6,7 & 84 & 93,3 \\
\hline 8 & Having sexual intercourse orally & 6 & 6,7 & 84 & 93,3 \\
\hline 9 & Buy people to have sexual relations & 12 & 13,3 & 78 & 86,7 \\
\hline 10 & Paid people to have sexual relations with respondents & 9 & 10 & 81 & 90 \\
\hline 11 & Have a tattoo & 18 & 20 & 72 & 80 \\
\hline 12 & Never tattooed using the same needle & 3 & 3,3 & 87 & 96,7 \\
\hline 13 & Share shavers & 7 & 7,8 & 83 & 92,2 \\
\hline
\end{tabular}


between the perception of vulnerability with HIV / AIDS prevention behavior. workers is not at risk in the transmission of HIV / AIDS. However, there are still some workers who have risk behaviors, such as not using a condom during sexual intercourse $(73.3 \%)$ and not always using a condom during sexual intercourse $(83.3 \%)$

\section{Univariate Analysis}

a. Relationship between Social Pressure with Risk Behavior of HIV/AIDS Transmission

The results of research on the relationship of social pressure with risk behaviors of HIV / ADIS transmission at Loading Workers in Padang City Harbor, the data below is obtained: Table 9.

The Relationship between Social Pressure and HIV / AIDS Risk Behavior at Loading Workers in Padang City Port in 2019

\begin{tabular}{|c|c|c|c|c|c|c|c|c|}
\hline \multirow{3}{*}{ No } & \multirow{3}{*}{$\begin{array}{c}\text { Social } \\
\text { Pr essure }\end{array}$} & \multicolumn{4}{|c|}{ Risk Behavior of HIV/AIDS } & \multirow{2}{*}{\multicolumn{2}{|c|}{ Amount }} & \multirow{3}{*}{$\begin{array}{c}\mathbf{P} \\
\text { Value }\end{array}$} \\
\hline & & \multicolumn{2}{|c|}{ No Risk } & \multicolumn{2}{|c|}{ Risky } & & & \\
\hline & & $\mathbf{F}$ & $\%$ & $\mathbf{F}$ & $\%$ & $\mathbf{F}$ & $\%$ & \\
\hline 1 & Good & 41 & 73,2 & 15 & 26,8 & 56 & 100 & 0 , \\
\hline 2 & Not Good & 15 & 44,1 & 19 & 55,9 & 34 & 100 & 00 \\
\hline & Total & 56 & 62,2 & 34 & 37,8 & 90 & 100 & 6 \\
\hline
\end{tabular}

Based on table 9. it can be seen that respondents who have good social pressure have more behavior that is not at risk of HIV / AIDS (41 people) than respondents with bad social pressure (15 people). Statistical test results obtained the value of $\mathrm{P}$ Value 0.006 which means that there is a significant relationship between social pressure with HIV / AIDS prevention behavior.

b. Relationship between Perception of Vulnerability with Risk Behavior of HIV/AIDS Transmission

The results of research on the relationship of perception of vulnerability with HIV / AIDS prevention behavior in loading workers, obtained data below:

Table 10.

The Relationship between Vulnerability Perception and Risk Behavior of HIV/AIDS Transmission at Loading Workers in Padang City Port in 2019

\begin{tabular}{|c|c|c|c|c|c|c|c|c|}
\hline \multirow{3}{*}{$\mathrm{N}_{0}$} & \multirow{3}{*}{$\begin{array}{l}\text { Perception of } \\
\text { Vulnerability }\end{array}$} & \multicolumn{4}{|c|}{ Risk Behavior of HIV/AIDS } & \multirow{2}{*}{\multicolumn{2}{|c|}{ Amount }} & \multirow{3}{*}{ PValue } \\
\hline & & \multicolumn{2}{|c|}{ No Risk } & \multicolumn{2}{|c|}{ Risky } & & & \\
\hline & & $\mathrm{F}$ & $\%$ & $\mathrm{~F}$ & $\%$ & $\mathrm{~F}$ & $\%$ & \\
\hline 1 & Good & 31 & 72,1 & 12 & 27,9 & 43 & 100 & \multirow{3}{*}{0,065} \\
\hline 2 & Not Good & 25 & 53,2 & 22 & 46,8 & 47 & 100 & \\
\hline & Total & 56 & 62,2 & 34 & 37,8 & 90 & 100 & \\
\hline
\end{tabular}

Based on table 10. it can be seen that respondents with a good perception of vulnerability have more risk-free behavior in HIV / AIDS transmission (72.1\%) compared to respondents with a perception of vulnerability that is not good (53.2\%). Statistical test results obtained a P Value of 0.065 which means there is no meaningful relationship c. Relationship between Knowledge with Risk Behavior of HIV/AIDS Transmission

The results of research on the relationship of knowledge with HIV / AIDS risk behavior in loading workers in the Port of Padang City, obtained the data below:

Table 11.

The Relationship between Knowledge and Risk Behavior of HIV/AIDS Transmission at Loading Workers in Padang City Port in 2019

\begin{tabular}{|c|c|c|c|c|c|c|c|c|}
\hline \multirow{3}{*}{$\mathrm{N}_{0}$} & \multirow{3}{*}{ Knowledge } & \multicolumn{4}{|c|}{ Risk Behavior of HIV/AIDS } & \multirow{2}{*}{\multicolumn{2}{|c|}{ Amount }} & \multirow{3}{*}{$\begin{array}{c}\mathrm{P} \\
\text { Value }\end{array}$} \\
\hline & & \multicolumn{2}{|c|}{ No Risk } & \multicolumn{2}{|c|}{ Risky } & & & \\
\hline & & $\mathrm{F}$ & $\%$ & $\mathrm{~F}$ & $\%$ & $\mathrm{~F}$ & $\%$ & \\
\hline 1 & Good & 32 & 61,5 & 20 & 38,5 & 52 & 100 & \multirow{3}{*}{0,876} \\
\hline 2 & Not Good & 24 & 63,2 & 14 & 36,8 & 38 & 100 & \\
\hline & Total & 56 & 62,2 & 34 & 37,8 & 90 & 100 & \\
\hline
\end{tabular}

Table 11. shows that most loading workers with good knowledge have risk-free behavior (32 people) compared to loading workers with bad knowledge. Statistical test results obtained a $\mathrm{P}$ Value of 0.876 which means there is no meaningful relationship between knowledge and risk behaviors of HIV / AIDS transmission.

\section{Discussion}

1. Univariate Analysis

a. Social Pressure

The results obtained that as many as $20 \%$ of loading workers get social pressure and $18.9 \%$ of loading workers do not get social pressure at the Port of Padang City in 2019. The results of the questionnaire analysis showed that as many as $3.3 \%$ of loading workers in the past year had friends who used narcotics and as many as $1.1 \%$ of WBP had been invited by they friends to use narcotics.

Susilowati's research results in Semarang and surrounding areas showed the proportion of HIV and AIDS incidence in the case group of respondents with injecting drug use status $(48.1 \%)$ was greater than that of the control group respondents who used injecting drug use $(22.5 \%)$. While the proportion of cases of respondents who did not use injecting drugs $(51.9 \%)$ was smaller than the control group who did not use injecting drugs (77.5\%) [9].

Mindayani and Hidayat research results at Class IIA Penitentiary in Padang City showed that $53 \%$ of WBP (Penitentiary Fostered Citizens) received social pressure and $47 \%$ of WBP did not get social pressure at Class IIA Penitentiary in Padang City in 2018. It was seen that as many as ( $58 \%$ ) WBP in the last year got friends who used narcotics and as many as (50\%) WBP had been invited by friends of WBP (Penitentiary Prisoners) using narcotics [10].

Attempts by a person to loading workers to do something contrary to the wishes of loading workers in the behavior of 
preventing transmission of HIV / AIDS are the pressures felt by loading workers while at the Port.

According to the researchers, social pressure from loading workers who use narcotics has a very strong influence on the transmission of HIV / AIDS because they have been invited to use narcotics.

Therefore, it is expected that Port officials will collaborate with related parties, such as the Padang City Health Office, to conduct direct monitoring of loading workers who are still using narcotics. Health workers are also expected to be able to provide counseling and demonstrations of the impact of narcotics use on loading workers. The Port Management issued a policy in the form of rules and gave strict sanctions against them who use drugs.

\section{b. Perception of Vulnerability}

Based on table 4. it can be seen that more than half of the $60 \%$ loading workers agree on the impact of contracting HIV / AIDS.

The results of this study are not in line with research conducted by Mindayani and Hidayat at the Class IIA Penitentiary in the City of Padang that there is no significant relationship between the perception of severity with HIV / AIDS transmission prevention behaviors with a P-Value of 0.658 . Respondents with good severity perception had less good prevention behavior in HIV / AIDS transmission (20\%) than respondents perceived bad severity (25\%) [10]. According to researchers, the perception of loading workers about the impact of contracting HIV / AIDS, can be improved through the provision of health information (leafleats, posters and banners), showing videos of HIV cases and their impact on health.

\section{c. Knowledge}

The results of this study are in line with research conducted by Pratiwi and Basuki in Indonesia that there is a significant relationship between sexual behavior with knowledge of HIV / AIDS prevention in adolescents aged 15-24 years ( $\mathrm{p}$ $=0,000$ at $\alpha=0.05$ ).

The results of this study are in line with research conducted by Chibtia Irsyad et al in Kudus Regency that adolescents in the street children community have knowledge of HIV / AIDS in the good category of 38 people $(69.1 \%)$ and in the unfavorable category of 17 people $(30,9 \%)$ [11].

The results of this study are not in line with research conducted by Mindayani and Hidayat on WBP (Penitentiary Prisoners) in Class IIA Penitentiary in Padang City that there is no meaningful relationship between knowledge and HIV / AIDS transmission prevention behavior with a $\mathrm{P}$ Value of 0.224 . Where respondents with good knowledge have more good prevention behavior in the transmission of HIV / AIDS (24\%) compared to respondents with poor knowledge (21\%) [10].

According to researchers, loading workers have good knowledge about HIV / AIDS transmission and prevention. Based on this, Port officials are expected to collaborate with the Padang City Health Office, to socialize and conduct continuous counseling on prevention of HIV / AIDS transmission so that loading workers can make preventive efforts against HIV transmission.

\section{d. HIV/AIDS Risk Behavior}

Based on table 10 it is known that generally the behavior of workers is not at risk in the transmission of HIV / AIDS. However, there are still some workers who have risk behaviors, such as not using a condom during sexual intercourse $(73.3 \%)$ and not always using a condom during sexual intercourse $(83.3 \%)$.

This study is in line with the Laksana and Lestari research which shows that heterosexual and homosexual men have a tendency not to use condoms during sexual intercourse [11].

\section{Bivariate Analysis \\ a. Relationship Between Social Pressure with Risk Behavior of HIV/AIDS Transmission}

Based on table 7. it can be seen that respondents who have good social pressure have more behavior that is not at risk of HIV / AIDS (41 people) than respondents with bad social pressure (15 people). Statistical test results obtained the value of $P$ Value 0.006 which means that there is a significant relationship between social pressure with HIV / AIDS prevention behavior.

This study is in line with Hardani's research which shows the relationship between subjective norms (social pressure) and HIV / AIDS risk transmission behavior in the AL TNI soldiers in Kobangdikal in 2013. From the results of Hardani's research) shows respondents who believe that people who are considered important or influencing it, namely family, friends, and the community will support respondents not to behave at risk of HIV / AIDS transmission, most people who are considered important in the lives of respondents provide sufficient support and approval so that respondents do not behave at risk of HIV / AIDS transmission [13].

Likewise in this study, the more social pressure from the environment around loading workers, it will affect to take risky actions in HIV / AIDS transmission.

With the existence of free sexual behavior in loading workers, it will indirectly affect risky behavior in the transmission of HIV / AIDS. Thus, to minimize HIV/AIDS risk behavior in loading workers caused by social pressure, there needs to be attention from Koperbam in the form of providing routine information on HIV / AIDS risk behavior in loading workers. In addition, it is suggested to Koperbam to collaborate with local health centers to carry out HIV testing, due to the existence of free sexual behavior at loading workers.

\section{b. Relationship Between Perception of Vulnerability with Risk Behavior of HIV/AIDS Transmission}

Based on table 8. it can be seen that respondents with a good perception of vulnerability have more risk-free behavior in transmission of HIV / AIDS (72.1\%) compared to respondents with a perception of vulnerability that is not good $(53.2 \%)$. Statistical test results obtained a P Value of 0.065 which means there is no meaningful relationship between the perception of vulnerability and HIV / AIDS transmission behavior. 
This research is opposite with Wulandari, et al.'s research showing that there is a significant influence between perception of vulnerability and sexually transmitted infections prevention behavior in female sex worker (FSW) in Banjarsari Surakarta $p=0.012$, where the stronger perception of vulnerability of a FSW, the greater the possibility of having healthy behavior in preventing sexually transmitted infections [14]. However, this study is in line with the study of Umam, et.al which shows that the perception of vulnerability is not related to HIV prevention behavior in University Students in Indonesia in 2017 [15]. This study did not show a meaningful relationship between perceptions of vulnerability and risk behaviors for HIV / AIDS transmission. Although loading workers has an assumption of vulnerability to contracting HIV / AIDS, the behavior still does not match their perceptions, because they are in a risky environment.

\section{c. Relationship Between Knowledge with Risk Behavior of HIV/AIDS Transmission}

Table 9 shows that most loading workers with good knowledge have risk-free behavior ( 32 people) compared to loading workers with bad knowledge. Statistical test results obtained a $\mathrm{P}$ Value of 0.876 which means there is no meaningful relationship between knowledge and risk behaviors of HIV / AIDS transmission.

This study is in line with Erniwaty's research, it was found that knowledge about HIV / AIDS had no significant relationship with HIV / AIDS prevention behavior $(\mathrm{p}=$ 0.723 ) with a confidence interval of 0.756-0.910 [16].

This research is also in line with Mindayani and Hidayat's research which shows that knowledge has no relationship with HIV / AIDS transmission prevention behavior in WBP in Lapas Class IIA Padang (10). However, this study is not in line with Margawati and Hargono, where the results show that knowledge has a relationship with sexual behavior at risk of HIV/AIDS transmission at loading workers in the Port of Kalimas Surabaya with a P Value of 0.013 [17].

According to Azwar knowledge is not directly related to a behavior in action and produces a positive value. This is caused in responding to a knowledge as a result of sensing, it takes a response in the form of a good attitude so that it changes or shapes a behavior or action [18].

According to Festinger in Azwar who put forward the theory of 'cognitive dissonance', that there is a human tendency to avoid behavior so that it is not in accordance with the attitude or knowledge may not correspond to the attitude and behavior. Humans are basically always logical and assumed so they try to maintain the consistency of the knowledge they have, but in fact they have to deal with the fact that human behavior is often irrational. Cognitive dissonance occurs when a person holds two different behaviors or when beliefs are not in line with the behavior. In addition, according to Rosenberg in Azwarkomponen knowledge is not only what is known about the object, but includes what is believed about the relationship between the object's attitude and affective value. Affective value is a person's feelings towards an object so that if the components of knowledge and feelings are considered good and in line with attitude, the three things are considered to be related.
However, if there are inconsistencies between the three things, the results are not related [19].

From the explanation of the theory above, it is very possible that the knowledge of loading workers is not related to risk behavior in HIV / AIDS transmission. Even though they already know about the risk of HIV / AIDS transmission, but with the influence of social pressure, the surrounding environment, it is very possible loading workers have a behavior not in line with the knowledge they have.

\section{CONCLUSION}

Based on the results of the study above, it can be concluded that there is a relationship between social pressure and HIV / AIDS risk behavior, and the absence of a relationship between social pressure and perceived vulnerability to HIV / AIDS risk behavior among loading workers at Padang City Port in 2019.

\section{ACKNOWLEDGMENT}

The researcher expresses his thanks to the Republic of Indonesia Ministry of Research, Technology and Higher Education as the budget giver in this study so that researchers can conduct this research well. Furthermore, the researchers also thanked the Chancellor of the University of Baiturrahmah, Dean of the Faculty of Public Health of the University of Baiturrahmah and colleagues who have helped in completing this research.

\section{REFERENCES}

[1] UNAIDS. 2017. UNAIDS Data 2017. Diakses dari: http://www.unaids.org pada tanggal 4 Agustus 2018 [2] Kemenkes RI. 2017. Laporan Perkembangan HIVAIDS dan Penyakit Infeksi Menular Seksual (PMS) Triwulan I Tahun 2017. Diakses dari: http://www.siha.depkes.go.id pada tanggal 1 Agustus 2018

[3] WHO. 2017. Kajian Nasional Respon HIV di Bidang Kesehatan Republik Indonesia. Jakarta

[4] Kemenkes RI. 2011. Surveilans Terpadu Biologis dan Perilaku 2011. Jakarta

[5] Depkes RI. 2009. Analisis Kecenderungan Perilaku Berisiko terhadap HIV di Indonesia. Jakarta. Diakses dari: http://www.siha.depkes.go.id pada tanggal 6 Agustus 2018।

[6] Kemenkes RI. 2015. Surveilans Terpadu Biologis dan Perilaku 2015. Jakarta

[7] Dinkes Kota Padang. 2018. Laporan Tahunan Dinas Kesehatan Kota Padang. Diakses dari: http://www.dinkes.padang.go.id pada tanggal 7 Agustus 2018

[8] Kemenkes RI, 2014. Infodatin: Situasi dan Analisis HIV AIDS. Diakses dari: http://www.depkes.go.id pada tanggal 12 Mei 2017 
[13] Hardani R. Hubungan Persepsi Siswa Dikmata TNI Al

[9] Susilowati, T. Faktor -Faktor Risiko Yang Berpengaruh Terhadap Kejadian HIV Dan AIDS di Semarang Dan Sekitarnya. 45-90-1-SM.pdf

[10] Mindayani S, Hidayat H. Hubungan Karakteristik Dan Tekanan Sosial Dengan Perilaku Pencegahan Penularan HIV/AIDS Pada Wbp Di Lapas Kelas IIA Padang. J Ris Hesti Medan Akper Kesdam I/BB Medan [Internet]. 2018;3(2):38-47. Available from: https://jurnal.kesdammedan.ac.id/index.php/jurhesti/article/ view/42

[11] Laksana, ASD , Lestar D. Faktor-Faktor Risiko Penularan HIV/AIDS pada Laki-Laki dengan Orientasi Seks Heteroseksual dan Homoseksual di Purwokerto. Manda Heal. 2010;40(2):113-23.

[12] Chibtia Irsyad, Noor Alis Setiyadi, Anisa Catur Wijayanti. Prodi Kesehatan Masyarakat FIK UMS. Prosiding Seminar Nasional Fakultas Ilmu Kesehatan ISSN 2460-4143 Update: Upaya Promotif, Preventif, dan Rehabilitatif dalam Penanganan Stroke. ISSN 2460-4143 dengan Perilaku Beresiko Penularan HIV/AIDS pada Prajurit Tni Al Di Kobangdikal Tahun 2013. 2013;01(01):53-65.

[14] Wulandari YA, Suryani N, Pamungkasari EP. Health Belief Model: Health Preventive Behavior of Sexually Transmitted Infection in Female Sex Workers in Surakarta. J Heal Promot Behav. 2016;01(02):70-8.

[15] Umam MK, Hemchayat M, Wetasin K. Persepsi tentang HIV/AIDS dan Perilaku Pencegahan HIV pada Mahasiswa Universitas di Indonesia. J Kesehat Reproduksi. 2017;8(1):31-40.

[16] Erniwaty. Hubungan Pengetahuan dan Sikap terhadap Perilaku Oencegahan HIV/AIDS pada Warga Binaan Pemasyarakatan (LAPAS) 2A Pontianak Tahun 2016. J Untan. 2018;4(1).

[17] Margawati K, Hargono A. Perilaku Seksual Berisiko Penularan HIV Pada Tenaga Kerja Bongkar Muat di Pelabuhan Kalimas Surabaya. J promkes. 2015;3(2):183-94.

[18] Azwar S. Sikap Manusia: Teori dan Pengukurannya. Sikap Manusia: Teori dan Pengukurannya. 2013. 